\title{
Antibiotic Resistant Genes in Natural Environment
}

\author{
Tejpreet Chadha* \\ Department of Biological Sciences, Texas Tech University, Lubbock, TX, 79415
}

\begin{abstract}
The excessive use of antibiotics has contributed to emergence of antibiotic resistance in pathogenic bacteria The environment and ecological habitats facilitate the transfer of the antibiotic resistance genes. To understand the pathogen ecology, it is now important to study antibiotic resistance in non-clinical natural habitats.
\end{abstract}

Keywords: Antibiotic resistance genes; Horizontal gene transfer; Ecosystem

\section{Introduction}

In early times, scientists considered antibiotic resistance in terms of adaptation to the toxic agents. For instance, Ehrlich worked on development of p-rosaniline resistance to Trypanosoma brucei as early as 1904. The resistance was observed during the treatment of trypanosome infections as the organisms emerged that were resistant to p-rosaniline. The drug inactivation was also discovered early as well [1]. In 1919, Neuschlosz reported Paramecium caudatum resistance to quinine and a dye that acquired the ability to destroy the toxic agent [1]. The emerging resistance in clinical isolates to penicillin was reported as early as 1941, resistance to sulfonamide in 1939 [2-4]. Miller and Bohnhoff observed resistance to streptomycin in 1947 [5,6]. The streptomycin was initially represented as the first breakthrough in the chemotherapy of tuberculosis [7]. However, relapses were soon observed with streptomycin-resistant Mycobacterium tuberculosis [8]. The resistance continued to develop for other antimicrobials as well. It was soon realized that resistance could emerge even in the absence of an antibiotic by transfer of antibiotic genes [1]. For instance, Hotchkiss demonstrated that penicillin resistance could be transferred to susceptible pneumococcus $[1,9]$. However, the most important step was to understand the prevalence of R-plasmids that help to better understand the resistance acquisition and dissemination [1]. The excessive usage of antibiotics in agriculture, aquaculture and livestock has resulted in selection for resistant bacteria [10]. The spread of antibiotic resistance genes by horizontal gene transfer via plasmids and mobile elements such as transposons has increased the acquisition of antibiotic resistance genes among species from antibiotic producers to commensal and pathogen bacteria [11,12]. Today, the focus is to understand the function of these resistance genes in their natural environmental hosts and understand the mechanisms involved in the emergence, and spread of antibiotic resistance.

\section{Antibiotic Resistance Genes in Nature}

One of the major concerns is distribution of antibiotic resistance in nature. Martinez [10] stated that "The analysis of bacterial isolates from pre-antibiotic era demonstrated that the copy number of different plasmids carried by pathogenic bacteria were essentially the same that can be found today". The pre-antibiotic plasmids did not carry the antibiotic resistance genes, therefore the acquisition and further dissemination among pathogenic bacteria is the consequence of strong antibiotic selective pressure as a result of antibiotic therapy [10]. Antibiotic resistance genes are mostly chromosomally encoded and are associated with mobile elements such as transposons. They can also be found in microbiotas that are not in contact with antibiotics $[13,14]$. The association of antibiotic resistance genes with mobile element has spread between bacteria of different species and genera via horizontal gene transfer (HGT). There is evidence that emergence of virulent strains of Salmonella in the food supply is linked to HGT $[15,16]$. The whole genome analysis has further shown that horizontal transfer has modified various genes, operons and islands within Salmonella chromosome [15]. However, the understanding of how HGT has altered the genomes of Salmonella pathogens can help to devise new risk evaluation strategies to detect this food borne pathogen [16,17]. The antibiotic resistance by horizontal gene transfer has a major role on the development and spread of antibiotic resistance genes.

The antibiotic resistance genes have originated in the environmental bacteria mostly as antibiotic producers. They are also known to have a physiological role $[18,19]$. One of the important examples is chromosomal penicillin binding proteins (PBP) that contribute to resistance to antibiotics $[20,21]$. The research literature has reported that PBP have evolved from transpeptidases that are physiologically involved in cell wall synthesis $[18,22,23]$. The resistance is commonly due to mutation or overproduction of PBP. For instance, Enterococcus faecium isolated from United States hospitals was shown to be highly resistant to ampicillin due to mutation or over production of the PBP5 $[24,25]$.

\section{Changes in Natural Ecosystem}

The change in environment has affected our natural ecosystem. The chemical pollution, industrial activities, mining, intensive farming have resulted in selection of antibiotic resistance determinants in the environment. The selection is favored due to ecological advantage to the bacterium in its habitat [26]. They have acquired various mechanisms for adaptation to changing environment. The research study has reported that co-selection/cross-selection is frequently linked on the same plasmid [27]. The disposal of domestic and industrial waste has affected human health and environment. The toxic effects of heavy metals such as copper, cadmium, lead, zinc, nickel, mercury and chromium can be toxic to plants, animals, humans and aquatic life when accumulated in soils at higher concentration [28]. The presence of heavy metal in soils is also responsible for their persistence in the food chain. This could spread the antibiotic resistance genes among

*Corresponding author: Tejpreet Chadha, Department of Biological Sciences Texas Tech University, Lubbock, Texas, 79415, E-mail: preeti.chadha@ttu.edugov

Received April 20, 2012; Accepted July 10, 2012; Published July 12, 2012

Citation: Chadha V (2012) Antibiotic Resistant Genes in Natural Environment Agrotechnol 1:104. doi:10.4172/2168-9881.1000104

Copyright: (c) 2012 Chadha V. This is an open-access article distributed unde the terms of the Creative Commons Attribution License, which permits unrestricted use, distribution, and reproduction in any medium, provided the original author and source are credited. 
bacterial populations. For instance, bacterial strains isolated from tannery waste water such as Flavobacterium sp have shown tolerance to copper, zinc, mercury and lead [28,29]. The Pseudomonas species isolated from the waste showed tolerance against all antibiotics except ciprofloxacin. The Pseudomonas species also showed tolerance to heavy metals such as lead, copper, zinc, mercury and chromium [28-31]. The clearance of industrial waste has also caused contamination of rivers and lakes. The research study has shown that Providencia stuartii strain isolated from contaminated river has shown resistance to all antibiotics including carbapenems [32]. The use of several classes of antibiotics in aquaculture, including sulfonamides, quinolones, macrolides, tetracyclines and emamectin has increased considerable risk of release of antimicrobials into the environment and eventually the possibility of development of resistance in pathogenic bacteria $[33,34]$.

\section{Antibiotics in Agriculture}

The excessive usage of antibiotics in agriculture, aquaculture and livestock may selects for resistant bacteria as large amount of antibiotics may find their way into natural habitats. The most commonly used antibiotic in agriculture is oxytetracycline and streptomycin [29]. The use of streptomycin has resulted in streptomycin-resistance strains of Erwinia amylovora, Pseudomonas species, and Xanthomonas campestris. The research study has reported that fraction of streptomycinresistance genes in plant-associated bacteria are related to those found in bacteria isolated from humans, animals, and soil, and are associated with mobile elements [35]. The use of antibiotics such as avoparcin, which is a glycopeptide antibiotic, as a growth promoter on poultry and pig farms has resulted in increase in resistance to vancomycin [36-38]. The genetic modified organism needs to be carefully analyzed before they are introduced in the field as they may cause spread of antibiotic resistance genes in the population. The usage of Burkholderia cepacia for bioremediation and as promoter for crop growth need to be analyzed as it may also cause infection in immune compromised patients $[39,40]$. The regulations to curb the use of excessive antibiotics should be implemented to prevent the spread of resistances.

\section{Conclusion}

The ecological communities are the product of biotic and abiotic forces that are influenced by habitat and environmental conditions [41]. The study of transmission, intrinsic resistance to antibiotics and tendency to accumulate resistance genes are needed to understand the underlying mechanism [42]. However, pathogen ecology is not a part of current antibiotic treatment guidelines. The current drug regimen is mainly based on clinicians experience rather than on systematic evaluation of the trade-off between treatment success and resistance [42]. This can potentially increase the rate at which the resistance evolves and spreads to other bacterial populations. For instance, there is evidence suggesting that the rise of vancomycin-resistant enterococci in the United States during the 1980s was probably driven by excessive use of oral vancomycin for Clostridium difficile $[37,42,43]$. The emerging resistance in bacterial species makes it more important to understand the relationships between dosage, pharmacokinetics and therapeutic efficacy from the standpoint of bacterial resistance [42]. However, guidelines based on differences and diversity in ecological dynamics for the same bacteria in different habitats in the body could contribute to dramatically reduce the volume of antibiotics consumed and selection for resistance [44-46]. The study of antibiotic resistance in natural ecosystems is still underway. The most important question that is not yet answered is distribution of antibiotic resistance genes in nature.

\section{References}

1. Mayers DL (2009) Antimicrobial Drug Resistance: Mechanisms of Drug Resistance (Humana Press, New-York)

2. Benveniste R, Davies J (1973) Mechanisms of antibiotic resistance in bacteria Annu Rev Biochem 42: 471-506.

3. Brandl E, Giovannini M, Margreiter H (1953) [Studies on the acid stable, orally efficacious phenoxymethylpenicillin (penicillin V)]. Wien Med Wochenschr 103: 602-607.

4. Bornstein S (1940) Action of Penicillin on Enterococci and Other Streptococci. J Bacteriol 39: 383.

5. Miller CP, Bohnhoff M (1947) On the mechanism of the development of streptomycin resistance. J Bacteriol 54: 8.

6. Miller CP, Bohnhoff M (1947) Two Streptomycin-resistant Variants of Meningococcus. J Bacteriol 54: 467-481.

7. Crofton J, Mitchison Da (1948) Streptomycin resistance in pulmonary tuberculosis. Br Med J 2: 1009-1015.

8. Schatz A, Bugie E, Waksman SA (2005) Streptomycin, a substance exhibiting antibiotic activity against gram-positive and gram-negative bacteria. Clin Orthop Relat Res 3-6.

9. Field SK, Fisher D, Cowie RL (2004) Mycobacterium avium complex pulmonary disease in patients without HIV infection. Chest 126: 566-581.

10. Martinez JL (2008) Antibiotics and antibiotic resistance genes in natura environments. Science 321: 365-367.

11. Martínez JL (2012) Natural antibiotic resistance and contamination by antibiotic resistance determinants: the two ages in the evolution of resistance to antimicrobials. Front Microbiol 3:1.

12. Aminov RI (2009) The role of antibiotics and antibiotic resistance in nature Environ Microbiol 11: 2970-2988.

13. D'Costa VM, McGrann KM, Hughes DW, Wright GD (2006) Sampling the antibiotic resistome. Science 311: 374-377.

14. Martinez JL, Fajardo A, Garmendia L, Hernandez A, Linares JF, et al. (2009) A global view of antibiotic resistance. FEMS Microbiol Rev 33: 44-65.

15. Brown EW, Mammel MK, LeClerc JE, Cebula TA (2003) Limited boundaries for extensive horizontal gene transfer among Salmonella pathogens. Proc Nat Acad Sci USA 100: 15676-15681

16. Brown EW, LeClerc JE, Li B, Payne WL, Cebula TA (2001) Phylogenetic evidence for horizontal transfer of mutS alleles among naturally occurring Escherichia coli strains. J Bacteriol 183: 1631-1644.

17. Wiedenbeck J, Cohan FM (2011) Origins of bacterial diversity through horizonta genetic transfer and adaptation to new ecological niches. FEMS Microbiol Rev 35: 957-976.

18. Martinez JL, Baquero F, Andersson DI (2007) Predicting antibiotic resistance. Nature Reviews Microbiology 5: 958-965.

19. Martinez JL (2009) Environmental pollution by antibiotics and by antibiotic resistance determinants. Environ Pollut 157: 2893-2902.

20. Jacoby GA (2009) AmpC beta-lactamases. Clin Microbiol Rev 22: 161-182.

21. Koch AL (2000) Penicillin binding proteins, beta-lactams, and lactamases: offensives, attacks, and defensive countermeasures. Crit Rev Microbiol 26 205-220.

22. Ogawara H, Kuma K, Miyata T (1993) Gene transfer of a part of a betalactamase gene? Microbiol Immunol 37: 399-403.

23. Ogawara H (1993) Phylogenetic tree and sequence similarity of betalactamases. Mol Phylogenet Evol 2: 97-111.

24. Kobayashi N, Alam M, Nishimoto Y, Urasawa S, Uehara N, et al. (2001) Distribution of aminoglycoside resistance genes in recent clinical isolates of Enterococcus faecalis, Enterococcus faecium and Enterococcus avium. Epidemiol Infect 126: 197-204.

25. Meroueh SO, Minasov G, Lee W, Shoichet BK, Mobashery S (2003) Structural aspects for evolution of beta-lactamases from penicillin-binding proteins. J Am Chem Soc 125: 9612-9618.

26. Wright MS, Austin $\mathrm{CB}$, Lindell AH, Stepanauskas R, Stokes HW, et al 
(2008) Influence of industrial contamination on mobile genetic elements: class 1 integron abundance and gene cassette structure in aquatic bacterial communities. ISME J 2: 417-428.

27. Timoney JF, Port J, Giles J, Spanier J (1978) Heavy-metal and antibiotic resistance in the bacterial flora of sediments of New York Bight. Appl Environ Microbiol 36: 465-472.

28. Tamil Selvi E, Anjugam E, Archana Devi R, Madhan B, Kannappan S, et al. (2012) Isolation and Characterization of Bacteria from Tannery Effluent Treatment Plant and Their Tolerance to Heavy Metals and Antibiotics. Asian J Exp Biol Sci 3: 34-41.

29. Ilias M, Rafiqullah IM, Debnath BC, Mannan KSB, Mozammel Hoq M (2011) Isolation and Characterization of Chromium(VI)-Reducing Bacteria from Tannery Effluents. Indian J Microbiol 51: 76-81.

30. Viti C, Pace A, Giovannetti L (2003) Characterization of $\mathrm{Cr}(\mathrm{VI})$-resistant bacteria isolated from chromium-contaminated soil by tannery activity. Curr Microbiol 46: 1-5.

31. Basu M, Bhattacharya S, Paul AK (1997) Isolation and characterization of chromium-resistant bacteria from tannery effluents. Bull Environ Contam Toxicol 58: 535-542.

32. Medeiros AA (1997) Evolution and dissemination of beta-lactamases accelerated by generations of beta-lactam antibiotics. Clin Infect Dis 24: S19-S45.

33. Zhang HG, Ma SS, Li QF, Fu XJ, Zhang Y, et al. (2011) Analysis of the changes of microbial community structure on bio-carrier of recirculating aquaculture systems (RAS). Huan Jing Ke Xue 32: 231-239.

34. Cabello FC (2006) Heavy use of prophylactic antibiotics in aquaculture: a growing problem for human and animal health and for the environment. Environ Microbiol 8: 1137-1144.

35. McManus PS, Stockwell VO, Sundin GW, Jones AL (2002) Antibiotic use in plant agriculture. Annu Rev Phytopathol 40: 443-465.
36. D'Costa VM, McGrann KM, Hughes DW, Wright GD (2006) Sampling the antibiotic resistome. Science 311: 374-377.

37. Bates J (1997) Epidemiology of vancomycin-resistant enterococci in the community and the relevance of farm animals to human infection. J Hosp Infect 37: 89-101.

38. Bager F, Madsen M, Christensen J, Aarestrup FM (1997) Avoparcin used as a growth promoter is associated with the occurrence of vancomycin-resistan Enterococcus faecium on Danish poultry and pig farms. Prev Vet Med 31: 95112

39. Goldmann DA, Klinger JD (1986) Pseudomonas cepacia: biology, mechanisms of virulence, epidemiology. J Pediatr 108: 806-812.

40. Thomassen MJ, Demko CA, Klinger JD, Stern RC (1985) Pseudomonas cepacia colonization among patients with cystic fibrosis. A new opportunist. Am Rev Respir Dis 131: 791-796.

41. Bell CW, Acosta-Martinez, McIntyre NE, Stephen Cox, Zak JC, et al. (2009) Linking microbial community structure and function to seasonal differences in soil moisture and temperature in a Chihuahuan desert grassland. Microb Eco 58: $827-842$.

42. Geli P, Laxminarayan R, Dunne M, Smith DL (2012) "One-size-fits-all"? Optimizing treatment duration for bacterial infections. PLoS One 7: e29838.

43. Udekwu KI, Parrish N, Ankomah P, Baquero F, Levin BR (2009) Functional relationship between bacterial cell density and the efficacy of antibiotics. J Antimicrob Chemother 63: 745-757.

44. Mouquet N, Devictor V, Meynard CN, Munoz F, Bersier LF, et al. (2012) Ecophylogenetics: advances and perspectives. Biol Rev Camb Philos Soc.

45. Cadotte MW, Davies TJ, Regetz J, Kembel SW, Oakley TH, et al. (2010) Phylogenetic diversity metrics for ecological communities: integrating species richness, abundance and evolutionary history. Ecol Lett 13: 96-105.

46. Violle C, Nemergut DR, Pu Z, Jiang L (2011) Phylogenetic limiting similarity and competitive exclusion. Ecol Lett 14: 782-787. 